\title{
THEORETICAL CONSIDERATIONS ON THE FORMATION OF COGNITIVE SKILLS IN STUDENTS OF SPORTS CLASSES
}

\author{
Mariana ARDELEAN \\ University of Medicine and Pharmacy of Târgu Mureș \\ mariana.ardelean@umfst.ro
}

\begin{abstract}
If the psychology and neurophysiology sciences clearly define the cognitive domain, they characterize it in all its aspects, providing the logistic support and the operational intervention framework necessary for the improvement of many domains, while the problem of the cognitive domain is not equally evolved, leaving room for interpretations. The failure to solve these problems, in terms of requirements that meet the demands of all applicants, is not due to the lack of specialists' concern, but to its objective and real difficulty created, on the one hand, by the cognitive genetic characteristics and the complex personality of the subject, and, on the other hand, the values and attitudes that are desired to be attained in relation to the objectives of the school cycle and the sports profile of the high school. Although the theories and the experimental studies project the contour of the subject on the cognitive field from different angles, they raise hypotheses, problems, they provide explanations and solutions, their implications on the learning efficiency and maximization of the psychic capacities of the individual remains a constant theme which is open to research, both from the anatomical- physiological point of view, as well as (or especially!) from the psycho-pedagogical and theoretical-practical points of view.
\end{abstract}

Key words: students, sports classes, competence, strength, critical thinking, efficiency.

\section{Introduction}

The centralized study of the problem addressed in theory and practice reveals the timeliness of this research, given that the aspect of cognitive competence formation at present is not fully analysed and does not fully meet the expectations of students and teachers, requiring a series of technological, strategic, methodological, additions etc., scientifically substantiated, which would illustrate the role and importance of the cognitive factor in the formation of the personality and the multilateral training of the pupils in sports high schools.

The formation of cognitive capacities and their transformation into competences is a constant problem approached in the specialty literature, constantly invoking the need to develop higher mental processes as a guarantee for the development of other types of skills that condition the efficiency of human actions. Given that they are structural assemblies of knowledge and skills acquired through learning, which allow the identification and solution in specific contexts of specific problems of a certain field of activity, the term of competence has different connotations. In the broad sense, competence means the ability of an individual to adapt according to his needs, his ability to acquire, to understand and to use an acquired skill [1]. In the specialized dictionaries the term of competence is associated with the following meanings: ability, skill, training, ability, qualification, talent, experience, authority in a particular field of activity $[3,4]$.
The meaning of the word "skill" to which Andrei Bontaş (1998) attributes another interpretation, "power" [2]. By analogy with the mathematical domain, respectively with one of the properties of the natural numbers, the transitivity, according to which "if $a=b$ and $\mathrm{b}=\mathrm{c}$, then and $\mathrm{a}=\mathrm{c}$ "” $[5,7]$, a concept can be derived whose significance can take multiple psycho-social and operational-practical interpretations [8]. By symbolically marking "a" for competence, "b" ability and "c" power, we have the following reasoning: "competence = ability, ability $=$ power $=>$ competence $=$ power".

If the psychology and neurophysiology sciences clearly define the cognitive domain, they characterize it in all its aspects, providing the logistic support and the operational intervention framework necessary for the improvement of many domains, while the problem of the cognitive domain is not equally evolved, leaving room for interpretations. The failure to solve these problems, in terms of requirements that meet the demands of all applicants, is not due to the lack of specialists' concern, but to its objective and real difficulty created, on the one hand, by the cognitive genetic characteristics and the complex personality of the subject, and on the other hand, the values and attitudes that are desired to be attained in relation to the objectives of the school cycle and the sports profile of the high school.

Although, in sports activity, the emphasis naturally falls on the development of motor skills, the psychic component remains the engine that energises the superior 


\section{THE ANNALS OF "DUNAREA DE JOS" UNIVERSITY OF GALATI \\ FASCICLE XV ISSN - 1454 - 9832 - Vol. 2/2019}

functions of the body. A. Dragnea (1999) points out that in the "improvement and over-learning" stage, attention is drawn to the major share of thinking, compared to the other stages, emphasizing that "over-learning" requires strong intellectual participation, a profound mental analysis of factual situations [6] , in the meaning that the cognitive factor accompanies the motor intelligence of the subject, it continues it and finalizes it, giving value to the action taken.

The questions that arise under these conditions are as follows: "Who has the essential role in the formation of cognitive skills, so strongly invoked in technical training, in order to achieve mastery, in tactical training in the form of tactical thinking, and in recent years even in psychological training in the form of emotional intelligence? The coaches in sports training or the teaching staff teaching theoretical subjects?"

Certainly both categories of specialists, but the major role is played by the teachers teaching in class. They are the ones who need to have the sources necessary for the formation, development and transfer of students' cognitive abilities into the practical area, and the coaches, without diminishing their own attributions, take over the cognitive acquisitions acquired by athletes and make them work in training and competitions.

Solving complex situations in training and competitions involves finding the shortest "way out" for knowledge, for learning the truth in a scientific sense: "However, there is a way out, because everywhere there are signs; their deciphering creates alternatives and man has to choose", said D. Rusti (1997), invoking Mircea Eliade [10].

\section{Research Methods}

The methods used in this study were: analysis of the specialized methodological-scientific literature and the analysis of the documents of the instructiveeducational process.

\section{Results and discussions}

One of the issues not fully elucidated in the theory and methodology of sports training concerns the common aspects that the two components require: theoretical training and psychological training. The confusions are determined by the roles they fulfill in the meaning that they transfer certain attributes, both claiming the formation of cognitive competences that will lead to solving various problems related to the school activities and the competitive exigencies demanded by the sport discipline practiced.

Another theme, which leaves room for many interpretations, is the basis on which the coach has to develop the cognitive capacities of the subjects in the theoretical training, given that, in the specialty theories and methodologies, the psychological training is most often invoked by the affective-emotional and volitional components, while less attention is given to the cognitive one. The issue regarding the cognitive capacities does not attract attention by the importance attributed to it in the specialized literature, especially by the lack of factual strategies of an operational nature to develop these capacities in the didactic process, which goal will be the formation of cognitive skills.

The ways in which high school students can train and develop their arsenal of cognitive skills to make their actions more efficient both in the classroom and in training and competitions remains a major priority for all factors involved in this direction.

Only when will the subjects be offered training and systematic education in class, the genetic background they have will be intellectually developed at a higher level and then transformed into skills to support their practical activity. Thus, a new way of teaching and evaluating school disciplines becomes mandatory through the use of the most innovative and effective teaching methods, to develop students' ability to perform logical operations, synthesize, compare, and explain with arguments using a sports specific language, since all initiatives and research investigations aim at progress.

In the didactic process, the level at which cognitive capacities can be developed is proportional, on the one hand, to the hereditary and intellectual background of the subject, and, on the other hand, to the effectiveness of the didactic strategies used by the instructor of the instruction-education process.

By putting students in factual situations to make different judgments, inductive, deductive and analogous, causing them to think divergently, to evaluate themselves, to transfer the knowledge acquired from one teaching content to another, to work with them and to use them in factual, practical situations, the premises are created for the development of their cognitive capacities and their integration in the environment where they carry out their activities.

The emphasis should be placed on the development of critical thinking, as it is disciplined and self-correcting thinking, and which assessment criteria are: clarity, precision, relevance, logic, and suitability to the purpose. It is an effective learning tool that helps the subject orientate himself in the possible alternatives and become aware of the mechanisms of his own thinking. The most important contribution is that it challenges to action; any understanding is followed by action. A. Nicu (2007) states that this kind of thinking "is a superior cognitive ability that implies intellectual autonomy, flexibility and a certain degree of constructive skepticism. The critical thinking is in close connection with the analytical thinking, the creative thinking and the metacognition" [9]. To think critically means to continually evaluate the plausibility and relevance of the data available, to be curious, to ask questions, to seek answers, to find alternatives to already established attitudes, to reasonably analyse the arguments of others, etc.

It should not be forgotten that each student has his own personality and intellectual abilities. These are not details of form, but aspects of primordial importance, they are pedagogical issues by excellence.

As a necessity, modern didactics has the obligation to develop and implement in practice new forms of 


\section{THE ANNALS OF "DUNAREA DE JOS" UNIVERSITY OF GALATI \\ FASCICLE XV ISSN - 1454 - 9832 - Vol. 2/2019}

teaching - learning - assessment of the didactic content, compatible with the intellectual level and the students' interests, leading to a clear, enhanced development of cognitive competences. The teaching strategies are efficient only when the teacher knows the individual characteristics of the subjects, of the assets, but especially the limits of their intellectual capacities. That is why the measures of didactic nature must aim at organizing and restructuring the internal psychological forces of the subject and bring them to light in the form of competences that will guarantee his integration in the environment in which he is living and dealing with.

The theoretical knowledge gained in the class, corroborated with practical experiences, must be internalized in value systems and externalized in the form of intellectual, affective and effector-operational (motor) attitudes.

To the extent that the subjects will be influenced by the educational process, they will develop their cognitive, volitional, but also rational-affective side, they will mature intellectually and will make efforts for selfrefinement, according to the specifics of the school activity and the applied sports discipline.

Based on this, the following rhetorical question arises on the subject invoked in the research: "The power to be competent or the competence as power?"

\section{Conclusions}

The formation and development of cognitive skills in students of sports classes depends essentially on the cultivation, in both directions, of the many theoreticalmethodological bridges created between the classroom and the practical reality on the field.

In both the didactic process and the practical work, the emphasis should be on the development of critical thinking, because to think critically means to continually evaluate the plausibility and relevance of the data available, to be curious, to ask questions, to seek answers, to find alternatives to already established attitudes, to reasonably analyse the arguments of others.
From a motivational perspective, competence (once formed) is that power of intrinsic, cognitive value resulting from the many capacities the individual holds and masters and which he can use in non-stereotyped situations. In this sense, competence (power) means: control capacity, decision-making capacity, critical thinking, logic, flexible thinking, creativity, efficiency (maximum yield with minimum effort).

All these goals can be achieved only if the teaching and evaluation methodology of the school disciplines is systematically improved and innovative didactic strategies will be designed to raise the curiosity of the subjects and to create those rational and motivational states which every individual needs in order to validate his creative abilities, in line with the specific requirements of the sports industry, the intellectual interests and aspirations.

\section{References}

1.Allen R. (2007), The Penguin Enghish dictionary, Third Edition: Penguin Books, London, p. 256.

2.Bontaș A. (1998), Dicționar Englez-Român. RomânEnglez, București, Editura Teora, p. 9.

3.Bucă M. (2003), Dicționar școlar de neulogisme, București, Editura Vox, p.105.

4.Bulgăre Gh. (1994), Dicționar de sinonime, București, Editura Palmyra, p. 56.

5.Caşu A., Goian I., Sârbu P. (2008), Sisteme numerice: pentru uzul studenților. Centrul de Educație și Cercetare în Matematică și Informatică, Chișinău.

6.Dragnea A. (1999), Antrenamentul sportiv. Teorie și metodică, București, Editura Didactică și Pedagogică R.A., p. $139-141$.

7.Ganga M. (2005), Matematică. Manual pentru clasa a Xa. Trunchi comun, Ploiești, Editura Mathpress, p. 162-169. 8. Miclea M. (2003), Psihologie cognitivă. Modele teoretico-experimentale. Ediția a II-a revăzută, Iași, Editura Polirom.

9.Nicu A. (2007), Strategii de formare a gândirii critice, București, Editura Didactică și Pedagogică, p. 6-18.

10. Rusti D. (1997), Dicționar de simboluri din opera lui Mircea Eliade, București, Editura Coresi, p. 157. 